\title{
An Empirical Study: Auditors' Characteristics and Audit Fee
}

\author{
Siheng Liu \\ Jinan University, Guangzhou, China \\ Email: liusiheng@hotmail.com
}

How to cite this paper: Liu, S.H. (2017) An Empirical Study: Auditors' Characteristics and Audit Fee. Open Journal of Accounting, 6, 52-70.

https://doi.org/10.4236/ojacct.2017.62005

Received: March 28, 2017

Accepted: April 25, 2017

Published: April 28, 2017

Copyright $\odot 2017$ by author and Scientific Research Publishing Inc. This work is licensed under the Creative Commons Attribution International License (CC BY 4.0).

http://creativecommons.org/licenses/by/4.0/

\section{(c) (i) Open Access}

\begin{abstract}
The existing literature about determinants of audit fee finds that those characteristics of a firm that conveys the "high quality" signal to the market can obtain higher audit fees. These studies ignore the differences among auditors, which are contradicted with individual auditor behavioral literature that showing different characteristics of auditors influence audit quality. Therefore, this paper hypothesizes that different auditors obtain different audit fees. Using the data of listed companies in China from 2010 to 2015, this paper constructs the regression model of the audit fees at individual auditor level and finds that age, gender, educational background, industry specialization, position and busyness all have significantly correlations with the audit fees. The results illustrate that audit client considers at individual auditor level when choosing audit services and pays different level of audit fees, which provide empirical evidences to selection and cultivation of auditors.
\end{abstract}

\section{Keywords}

Audit Fee, Audit Quality, Individual Characteristics of Auditor

\section{Introduction}

Audit fee is the economic remuneration for auditors who provide audit services, which are an agency fee according to certain standards. The audit fee includes the total cost of audit through the overall audit work, the risk compensation and the profit demand. During the actual audit work, the audit fee influences not only audit quality, but also the development of accounting firms and audit industry.

Therefore, audit fee is always the research focus of domestic and foreign scholars. Simunic [1] first explores the determinants of audit fees using empirical evidence. He finds that the complexity of the business, asset size, asset-liability ratio, etc. all affect the level of audit fees. From then on, many scholars continue to study the determinants of the audit fees basing on Simunic's audit fee model. 
Some scholars find that the market can recognize the characteristics that convey "high quality" signal and are willing to pay audit fee premiums to them. For example, "Big 4" usually obtain audit fee premiums [2] [3] [4], because audit clients believe that "Big 4" have higher audit quality [5] [6]. Besides, some researches find that there are different levels of audit fees among "Big 4" [7] [8], and illustrate that the firms with industry specialization can acquire audit fee premiums [9] [10] [11] [12].

However, these studies are based on an implied assumption that determinants of audit fees only exist at the firm level and there is no difference of audit quality and audit fees at individual auditor level, which is significantly contrary to existing auditor behavior literature. Some scholars have found that there is no audit premium for firm's industry specialization when controlling auditor's industry specialization [13]. In addition, a large number of researches of individual auditors' behavior reveal that there are differences between auditors, and different characteristics of them affect the individual's cognitive and behavior [14] [15] [16] [17], which finally affect audit quality [18] [19] [20]. There are also studies finding that the auditors at the same firm receive different remuneration, which means that the firm believes that the value created by the auditor is different [21]. This evidence suggests that the differences between auditors who are direct implementers of audit projects can affect audit quality, which is also recognized by the market. In addition, managers of audit clients, as the direct contactors of auditors, concentrate more at the individual auditor level than firm level to form the opinions of audit quality, even if these factors do not affect audit quality of financial statements [22]. The managers of audit clients are also negotiators of audit fees, which means they have decision-making power on audit fees. Therefore, it can be assumed that different auditors can obtain different audit fees.

Based on the above theories, this paper studies the determinants of audit fees at individual auditor level, including seven characteristics of the auditor's (the characteristics of the population and profession). In our research design, we assign an indicator variable to each auditor who signs audit reports for multiple clients for multiple years. We then estimate an audit-fee model by including these indicators, and control for audit client, audit firm, year and industry effects that could possibly affect audit fees. The results find that demographic and professional characteristics of auditors have significant influence on audit fees: age and gender have significant positive correlations with audit fees, while education background, industry specialization, position, number of audit year and busyness all have positive correlations with audit fees. These results suggest that individual auditors differ to a notable extent in terms of audit fees.

We conduct two additional tests to examine the robustness of these findings. In one test, we measure the explanatory variables in another way, by combining the two auditor features for the year into an integrated variable. In another test, we expand the test year length to measure whether the relationship between auditor characteristics and the audit fees is influenced by the external policy. The 
robustness results are almost consistent and the explanatory variables still have significant effects on the explanatory variables in these two robustness tests.

This paper contributes to two areas theoretically and practically. Firstly, this paper contributes to the broad literature examining links between individual auditors' characteristics and audit fees. We study the determinants of the audit fees from the perspective of individual audit level, rather than merely from the perspectives of audit clients and audit firms. The results show that audit clients consider not only at audit firm's level but at individual auditor's level as well, reflecting the "people-oriented" feature in the audit industry. In sum, this paper provides a more detailed research perspective from individual level and enriches the audit fee researches.

Secondly, this paper also has some practical significance for the development of China's audit market. From 2014, Chinese regulators have changed the audit charging mode from mandatory government guidance price to market price, which arises doubts that Chinese audit market is imperfect and not ready to execute market price. In this paper, we find that the individual characteristics of the auditor that deliver the signal of "high quality" can be recognized by the audit clients and obtain higher audit fees, which reveals that Chinese audit fee market is ordered because the price can follow the principle of marketization. In addition, this paper provides suggestions to China's Ministry of Finance, China Institute of Certified Public Accountants and other institutions to develop accounting personnel training program to strengthen the younger generation of auditor's professional skills education.

The remainder of this paper is organized as follows. The literature review is discussed in the second section. The third section discusses the underlying theory and research hypothesis. The forth section discusses the research design and the fifth section presents the empirical results. Some concluding comments are offered in the final section.

\section{Literature Review}

The existing literature of audit fees is mainly based on two perspectives, the perspective of auditees and auditors.

1) Audit client

From the perspective of audit client, Simunic [1] first uses empirical method to study the audit fee determinants and finds that the complexity of the business and asset size affect the level of audit fees. Firth and Francis [23] and Stokes [3], using the data of different countries during different time, both find that the size of the audit clients and the complexity of the economic business are important determinants of audit fees. Chinese scholars draw the same conclusions. Han Houjun and Zhou Chunsheng [24], Liu Bin [25], Zhang Jixun and Xu Yi [26], Fang Qiaoling and Li Xiaoyan [27] use the data of Chinese listed companies also find that audit client's size and complexity of economic business influence the audit fees.

Several scholars try to find the correlation between company governance and 
audit fees. Collier and Gregory [28] find that the existence of the audit committee is significantly positively correlated with the audit fees, based on the UK audit market. They think that audit committee can ensure the integrity of the auditors and prevent auditors from reducing audit time, thereby increasing the audit fees. Carcello et al. [29] examines the relationship between management characteristics (independence, diligence and professionalism) and audit fees, based on the data of top 1000 companies from Fortune List, and find that managers with high degree of independence, diligent and professional management characteristics incline to get high audit quality and pay higher audit fees. Like the study of domestic scholars, Cai Jifu [30] finds that the size of the board of directors, major shareholder holdings, CEO duality and the nature of enterprises all have significant collations with the audit fees. He finds that high efficient companies can reduce the audit fees. He Weifeng and Liu Wei [31] construct a manager-company pairing data by tracking managers who have at least two years of work experience in two listed companies for a period. They find that managers with more abilities pay less audit fees.

Besides, some scholars find corporate risk influence audit fees. Bell et al. [32] find that with the increase in the business risk of the audit client, the total audit time increases while the unit audit fee does not change, indicating that the auditors consider the business risk suffered by the audited entity when judging the audit risk and thereby increasing the audit time. Abbott, Parker and Peters [33] consider the impact of litigation risk on the audit fees and find that positive discretional accruals are significantly positively correlated with the audit fees, while negative discretional accruals are negatively correlated with the audit fees, indicating that the positive discretional accruals are riskier than the negative discretional accruals to the auditors. Similarly, domestic scholars draw the same conclusions. Wu Lina [4] uses the return on equity (ROE) of the audit clients as a measure of earnings management, and finds that the company's risk will lead to an increase in the audit fees. Zhao Guoyu and Wang Shanping [34] find that although the earnings management of the audited entity increases the audit fees, it does not affect the audit independence. Song Yanheng [35] examines the relationship between the punished companies and the audit fees, and finds that the audit fees of the audit clients who are subject to the relevant penalties are significantly higher than other companies.

2) Audit firm

From the perspective of auditors, majority of scholars consider the factors at firm level. Simunic [1] and Firth [23] find that firm size does not have a significant correlation with the audit fees. Domestic scholars, Li Buxi and Wang Pingxin [36] base on the data of A-share listed companies of 2002 in China, also draw the consistent conclusion. However, Francis [2] and Francis and Stokes [3] find that the firm size is significantly correlated with the audit fees based on data from Australian listed companies. Domestic scholar Wu Lina [4] bases on the data of Chinese listed companies in 2000 and 2001 and finds that "big 5" have higher audit fees. 
Besides, some scholars find firm's industry specialization influence the audit fees. Craswell et al. [9], based on the data from 1484 listed companies in Australia, find that the "Big Eight" of the industry can earn 34\% audit fee premiums than other firms. DeFond et al. [10] use the data of Hong Kong audit industry and find that industry "Big Six" charge higher audit fees. Basioudis et al. [11] and Carson and Fargher [12] draw the same conclusions. These empirical results indicate that the audit client is willing to pay audit fee premiums for the firm that delivers the "high quality" signal.

It can be seen from the above literature that the determinants of the audit fees mostly at audit client level, and the studies from the perspective of auditor level are mostly studied at firm level, without considering the difference among individual auditor level. Therefore, this paper which studies the determinants of the audit fees at individual auditor level is of theoretical importance.

\section{Research Hypothesis}

From the perspective of auditor's individual characteristics, this paper refers to the demographic research method to examine whether audit clients will consider at individual auditor level when choosing audit services and pay audit fee premiums to auditors who convey "high quality" signals.

It can be seen from the existing literature of audit fee determinants that the determinants of the audit fees can be measured from the audit client and auditor level. From the perspective of the relationship between the firm and the audit fees, it can be found that firms which deliver "high quality" signals to market tend to receive audit fee premiums. For example, "Big 4" are found to receive higher audit fees than other firms. It is worth noting that these studies are based on an implicit assumption that auditors at the firm provide the same audit quality and receive the same audit fees. This is contrary to the conclusions drawn by the existing literature of individual auditor's characteristic, which reveal that there are differences among auditors and their individual characteristics act directly on the cognitive styles and decision-making behaviors and thereby affecting audit quality.

On the other hand, because of lacking information and knowledge, external financial statement users form opinions of audit quality mainly basing on broad measures of audit quality, such as the firm's reputation and firm's size. But this assumption ignores another group of important users of audit service, the managers of audit clients. Unlike external financial reporting users, managers have more close contacts and communication with auditors and attempt to get more services from auditors, such as getting advice on the internal control, even if these services do not influence audit quality perceived by external users of financial statements. It has been found that auditors will choose auditors based on different needs: the motivation for small firms to choose auditors is to improve corporate governance while the motivation for large firms to choose auditors is to obtain external financing advice [37]. These "additional services" will not affect the opinions of external financial reporting users to judge the quality of the 
audit, but influence the managers' perceived audit quality. And managers are the negotiators of the audit fees and have power to make decisions on choosing audit services. Therefore, the determinants of the audit fees cannot be measured only at firm level, but should be measured at the individual audit level as well. Therefore, this paper will study the determinants of the audit fees at individual auditor lever basing on different characteristics of auditors.

1) Age

Age usually affects the tendency of risks. Some scholars believe that elder people tend to be more mature and don't like risks [38]. Paulsen et al. [39] find that the risk tendency decreases linearly with age, and those elder people have higher sensitivity to economic risk. Therefore, during the actual audit process, elder auditors are more cautious than younger auditors. In addition, according to the traditional Chinese Confucianism, age usually represents the experience, and those elder auditors are easier to acquire trust from audit client, and can acquire audit premium. Thus, we make the hypothesis:

H1: Auditor's age has a significant positive correlation with the audit fees.

\section{2) Gender}

Cognitive psychology and marketing theory believe that gender may affect the individual's judgment, and that women are good at dealing with complex tasks because women have better abilities to distinguish differences and integrate decision-making clues than men. Therefore, when dealing with tasks, women deal with information more accurately and efficiently than men. Based on this hypothesis, Chung and Monroe [40] find that there are differences between women and men's judgement modes: men are more accurate in judging simple tasks while women are more accurate in judging complex tasks. Borkowski and Ugras [41] judge differences of gender from a moral point of view and find that men are more utilitarian than women.

A series of experimental studies have examined the attitudes towards the risk between men and women, and find that in most cases, women are more likely to avoid risk than men. Women usually choose less risky and more secure behavior than men [42]. Graham et al. [43], Eckel and Grossman [44] and Fellner and Maciejovsky [45] also find that women's preference for risk is much lower than that of men. As for auditors, it is found that female auditors are more likely than men auditors to detect errors and fraud in financial reporting, and the audit quality of women is higher than one of men [18] [46];. So, whether the audit client can identify this feature and is willing to pay the premium should be considered. Thus, we make the hypothesis:

H2: Gender has a significant negative correlation with the audit fees.

3) Education Background

Spence [47] proposes that the educational background conveys "high quality" signal to the market. Because educational background often means learning ability to cope with complex decision-making situation. Lichtenstein and Fishchoff [48] find that education experience influence people's decision-making process that people with advanced degrees are more inclined to collect information 
about the decision-making, and can realize the deviation during process of making decision, which helps make decision-making more robust. In addition, Bonner and Walker [49] finds that the higher the degree of education and the more accounting knowledge, the more cautious in audit plan. Based on this assumption, auditors with higher degree of education can deal with audit work more easily and provide better audit quality [50]. Therefore, it should be considered whether audit clients recognize the "high quality" signal conveyed by education background and pay audit premium. Thus, we make the hypothesis:

H3: Education background of auditors has a significant positive correlation with the audit fees.

4) Industry Specialization

The audit industry expertise is a unique industry knowledge arisen from the continuous services of auditors in the same industry [20]. This industry expertise cannot be transferred at firm freely, which is owned by the individual auditors.

Specifically, this expertise is based on the auditors' deep understanding of industry operating characteristics and operational risks, which should be cultivated by experience. This industry expertise helps auditors to better and more effectively identify the financial risks of the industry's clients, help formulate more appropriate audit plans and implement appropriate auditing procedures, and ultimately produce reasonable audit opinions. Thus, audit expertise generally means higher audit quality [18] [51]. Zerni [52] finds that the auditor's individual industry expertise can obtain the audit premium. These studies show that audit clients can identify industry specialization at individual auditor level and are willing to pay audit fee premiums. Thus, we make the hypothesis:

H4: Auditor's industry specialization has a significant positive correlation with the audit fees.

5) Position

A series of studies find that firm partners are more cautious than other auditors [53]. Because the partners of the firm own and manage the firm, and they are not only punished by the regulators, but also suffer a greater loss from diminishing of firm's reputation when encountering audit failure. In addition, with the promotion of position, the auditor's reputation mechanism gradually plays a role, and the cost of the audit failure increases [50]. Then, the firm partners will be more cautious during audit process to prevent the risk of audit failure litigation.

On the other hand, "partner" is the top of auditor profession, which usually represents sufficient professional competence and a sense of professional ethics, and delivers "high audit quality" signal to the market. Therefore, audit clients are likely to pay higher audit fees to partners. Thus, we make the hypothesis:

H5: "Partner" position has a significant positive correlation with the audit fees.

6) Number of Audit Year

DeAngelo [54] finds that there is a learning effect in the field of audit. And studies of some scholars provide indirect evidence for the existence of learning 
effects in the audit industry [55]. Usually, longer audit year means more audit experience, help improve abilities to find fraud and misstatement [56] [57] [58], and reduce reliance of auditors on biased information provided by managers [59]. It can be argued that the increase in audit experience arisen by the number of audit year conveys the signal of "high quality" to the market and audit clients are willing to pay higher audit fees to obtain high audit quality. Thus, we make the hypothesis:

H6: The number of audit year has a significant positive correlation with the audit fees.

7) Busyness

Whether the auditor's busyness will affect the auditor's decision-making and work is argued by scholars at home and abroad. On the one hand, too many audit tasks will distract the auditors' attention, weaken the auditors' energy in each project, and influence audit decisions, resulting in the decline of audit quality [19]. However, according to the reputation hypothesis, high busyness usually means high reputation and professional competence [60]. For auditors who have more audit projects, their ability must be affirmed. In addition, the audit project is mainly concentrated in November to March each year, the time which is "busy season", and because of the increase of the needs of auditors, the audit clients are considered to pay higher audit fees to acquire reasonable audit service [2]. Therefore, from the point of view of demand and supply, the reasonable degree of busyness also represents the high demand of the auditors, and the audit clients may be willing to pay audit premium to purchase high quality service. Thus, we make the hypothesis:

H7: Audit busyness has a significant positive correlation with the audit fees.

\section{Research Design}

\section{1) Variables Definition}

In this paper, we refer to the method of Chin and Chi [18] to measure the audit industry specialization by the cumulative number of signature of auditor $i$ on audit report for industry $k$ before $t$ years. Balsam et al. [61] point out that industry specialization is arisen from the repetition audit in an industry. Therefore, for individual auditors, auditing industry expertise can be measured using the cumulative number of auditors in an industry.

$$
\text { Spe }=\sum_{j=1}^{j=t-1} \text { Freq }-P_{i, j, k}
$$

In terms of measurement of busyness, this paper refers to the method of Goodwin and $\mathrm{Wu}[62]$ to measure the total number of auditors' tasks in year $i$ as busyness.

$$
\text { Busyness }=\sum_{j=1}^{j=t-1} \text { Freq_ } P_{i, j}
$$

Referring to existing audit fee literature, this paper controls other factors that affect audit fees, including audit opinion, big 10, whether to switch the firm 
(Switch), Earnings Management (Em), the percentage of inventory and account receivable on total assets(Complexity), asset-liability ratio (Lev), company annual revenue growth rate (Growth), company size (Size), whether the company is punished (Punish) and whether the company's net profit for the year is negative(Loss). Table 1 describes the variable definitions.

\section{2) Empirical Models}

Based on the above theoretical analysis and assumptions, this paper establishes the following models.

First, all the auditor's individual characteristics and control variables are incorporated into the equation to establish model (1).

$$
\begin{aligned}
\text { Fee }= & \alpha_{0}+\alpha_{1} \text { Age }+\alpha_{2} \text { Gender }+\alpha_{3} \text { Edubg }+\alpha_{4} \text { Spe }+\alpha_{5} \text { Partner }+\alpha_{6} \text { Length } \\
& +\alpha_{7} \text { Busyness }+\alpha_{8} \text { Em }+\alpha_{9} \text { Big10 }+\alpha_{10} \text { Risk }+\alpha_{11} \text { Opinion } \\
& \alpha_{12} \text { Switch }+\alpha_{13} \text { Lev }+\alpha_{14} \text { Grow }+\alpha_{15} \text { Size }+\alpha_{16} \text { Punish } \\
& +\alpha_{17} \text { Loss }+\sum \gamma_{j} \text { Year }_{j}+\sum \delta_{k} \text { Industry }+\varepsilon
\end{aligned}
$$

Then, single individual characteristic is put into the equation respectively to

\begin{tabular}{|c|c|c|c|}
\hline Category & \multicolumn{2}{|c|}{ Code } & Definition \\
\hline $\begin{array}{l}\text { Explained } \\
\text { Variable }\end{array}$ & \multicolumn{2}{|c|}{ Fee } & Audit fee, measured by the natural logarithm of the company's audit fee \\
\hline \multirow{5}{*}{$\begin{array}{l}\text { Explaining } \\
\text { Variables }\end{array}$} & \multicolumn{2}{|c|}{ Spe } & $\begin{array}{l}\text { Industry Specialization, measured by the cumulative number of signature of auditor } \mathrm{i} \text { in industry } \\
\mathrm{k} \text { before year } \mathrm{t}\end{array}$ \\
\hline & \multicolumn{2}{|c|}{ Age } & Auditor's age \\
\hline & \multicolumn{2}{|c|}{ Edubg } & Auditor's education background, is 1 for bachelor degree or above, and 0 otherwise \\
\hline & \multicolumn{2}{|c|}{ Partner } & Whether the auditor is partner, is 1 for partner, and 0 otherwise \\
\hline & \multicolumn{2}{|c|}{ Exp } & Number of audit year, measured by the time of year i deducting the year of registration of CPA \\
\hline \multirow{10}{*}{$\begin{array}{l}\text { Control } \\
\text { Variables }\end{array}$} & \multirow{3}{*}{$\begin{array}{l}\text { Firm's } \\
\text { Characteristics }\end{array}$} & Opinion & Audit Opinion, is 1 for modified audit opinion, and 0 otherwise \\
\hline & & Big 10 & Top 10 firms in year $i$, is 1 for the company which is audited by "big 10 ", and 0 otherwise \\
\hline & & Switch & Whether switch the firm, is 1 if the company switch the firm, and 0 otherwise \\
\hline & \multirow{7}{*}{$\begin{array}{c}\text { Auditee's } \\
\text { Characteristics }\end{array}$} & Em & Earnings management, extraordinary item/ absolute value of profit for the year \\
\hline & & Complexity & Complexity of economic business, the sum of inventory and account receivables/total asset \\
\hline & & Lev & Solvency, asset-liability ratio \\
\hline & & Grow & Development capacity, revenue growth rate \\
\hline & & Size & Asset size, natural logarithm of total assets at year end \\
\hline & & Punish & Governance risk, is 1 if the company is punished by regulators, and 0 otherwise \\
\hline & & Loss & Financial risk, iss 1 if profit for the year is positive, and 0 otherwise \\
\hline
\end{tabular}
establish model (2).

$$
\begin{aligned}
\text { Fee }= & \alpha_{0}+\alpha_{1} \text { Characteristic }+\alpha_{2} \text { Em }+\alpha_{3} \text { Big10 }+\alpha_{4} \text { Risk }+\alpha_{5} \text { Opinion } \\
& +\alpha_{6} \text { Switch }+\alpha_{7} \text { Lev }+\alpha_{8} \text { Grow }+\alpha_{9} \text { Size }+\alpha_{10} \text { Punish }+\alpha_{11} \text { Loss } \\
& +\sum \gamma_{j} \text { Year }_{j}+\sum \delta_{k} \text { Industry }+\varepsilon
\end{aligned}
$$

Table 1. Variable definition. 


\section{Empirical Results}

1) Sample and data

We first collect data of Chinese listed companies at China Stock Market and Accounting Research database (CSMAR), and cross-check the identities of signing auditors against the enquiry system compiled by the CICPA (available at http://cmis.cicpa.org.cn, in Chinese). Data on individual auditors' demographic information are also obtained from this source. We manually input each auditor's full name into the relevant search fields and match the search results with the audit firm and individual auditor data collected from companies' annual reports. We start our sample period at fiscal 2010 to mitigate the possible effects of the promulgation and the implementation of 2010 audit standards. And we drop publicly listed companies in financial sector and observations with missing value, resulting in a total of 22,728 observations from 2010 to 2015 in our final sample.

2) Descriptive Statistics

Table 2 shows the descriptive statistics of variables used in models. To mitigate the undue influence of outliers, we winsorize all the continuous variables at the bottom and top 1 percentiles. For Fee, the mean is 13.47, ranging from 12.30 to 15.32 , indicating that the gap between the sample is not large. For auditor's age, the mean is 41.17 , the minimum is 27 years old while the maximum is 60

Table 2. Descriptive statistics.

\begin{tabular}{|c|c|c|c|c|c|c|}
\hline Variable & Obs & Mean & Median & Std.Dev. & Min & $\operatorname{Max}$ \\
\hline Fee & 22,728 & 13.47 & 13.38 & 0.590 & 12.30 & 15.32 \\
\hline Age & 22,728 & 41.17 & 41 & 6.725 & 27 & 60 \\
\hline Gender & 22,728 & 0.694 & 1 & 0.461 & 0 & 1 \\
\hline Edubg & 22,728 & 0.741 & 1 & 0.438 & 0 & 1 \\
\hline Spe & 22,728 & 9.195 & 5 & 11.20 & 1 & 57 \\
\hline Partner & 22,728 & 0.594 & 1 & 0.491 & 0 & 1 \\
\hline Exp & 22,728 & 11.70 & 12 & 5.339 & 1 & 25 \\
\hline Busyness & 22,728 & 3.111 & 2 & 2.375 & 1 & 16 \\
\hline Big10 & 22,728 & 0.488 & 0 & 0.500 & 0 & 1 \\
\hline Em & 22,728 & 0.0105 & 0.0046 & 0.0192 & $2.20 \mathrm{e}-07$ & 0.142 \\
\hline Complexity & 22,728 & 0.274 & 0.249 & 0.175 & $1.00 \mathrm{e}-05$ & 0.892 \\
\hline Switch & 22,728 & 0.0780 & 0 & 0.268 & 0 & 1 \\
\hline Opinion & 22,728 & 0.0260 & 0 & 0.159 & 0 & 1 \\
\hline Lev & 22,728 & 0.444 & 0.441 & 0.216 & 0.0409 & 0.899 \\
\hline Size & 22,728 & 9.540 & 9.474 & 0.536 & 8.287 & 11.20 \\
\hline Punish & 22,728 & 0.179 & 0 & 0.383 & 0 & 1 \\
\hline Loss & 22,728 & 0.0878 & 0 & 0.283 & 0 & 1 \\
\hline Grow & 22,728 & 0.468 & 0.039 & 8.940 & -40.35 & 52.42 \\
\hline
\end{tabular}


years old. For auditor's education background, $74.1 \%$ auditor has bachelor degree or above, indicating that auditor degree is dominated by bachelor degree. For industry specialization, the mean is 9.20 , the minimum is 1 while the maximum is 57 , indicating there is a big gap of industry specialization among auditors. For position, the number of firm partner accounts for $59.4 \%$ of total auditors. For number of audit year, the mean is 11.70 , indicating that auditors need audit experience. For busyness, the mean is 3.11 , and the maximum is 16 which is a rarely case. And there is no significant difference between mean and medium, so this paper uses OLS regression.

3) Regression Results

Table 3 shows the results of the two models. Column 1 is the result of the test of model (1) and Columns (2)-(8) are the test results for model (2). From the column (1) of Table 3, the age, gender, educational background, industry specialization, position, the number of audit year and the busyness are significantly correlated to the audit fees.

Specially, auditor age is significantly negatively correlated with the audit fees at $1 \%$ level, which is contrary to our expectation, the reason of which might be that younger auditors have better learning skills and energy than elder auditors and can adapt to changing standards and busy audit work. Therefore, the younger auditors are more welcomed by audit clients. The auditor's gender is significantly negatively correlated with the audit fees at the $1 \%$ level, indicating that audit clients are more willing to provide audit fee premiums for female auditors because the female auditor is more cautious in the audit process and has a higher practice ethics. There is a significant positive correlation between the auditor's educational background and the audit fee at $1 \%$ level, indicating that the audit clients can identify the "high quality" signal conveyed by the educational background. Audit industry specialization is significantly positively correlated with the audit fees at $10 \%$ level, indicating that audit industry specialization is one of the "high quality" signals. Whether the auditor is partner significantly positively correlates with the audit fee at $1 \%$ level, indicating that the audit clients believe that the position affects audit quality. There is a significant positive correlation between the number of audit year and audit fees at $1 \%$ level, indicating that the audit clients prefer auditors with longer audit year. Auditor's busyness has a significant positive correlation with audit fee at $5 \%$ level, indicating that those busier auditors have a higher reputation and audit quality and are favored by audit clients. These results indicate that the audit clients not only consider the firm factors, but also consider the individual characteristics of the auditors when choosing audit service, and willing to pay audit premium to characteristics that convey "high quality" signals.

The regression results of columns (2)-(8) of Table 3 are substantially the same as those of column (1), except for the number of audit year. The result shows that the number of audit year has no correlation with the audit fee. But it is found that the number of audit year should be considered by controlling age variables at the mean time. 
Table 3. Regression results.

\begin{tabular}{|c|c|c|c|c|c|c|c|c|}
\hline Variables & (1) & (2) & (3) & (4) & (5) & (6) & (7) & (8) \\
\hline \multirow[t]{2}{*}{ Age } & $-0.0065^{\star * *}$ & $-0.0041^{\star * *}$ & & & & & & \\
\hline & $(-11.71)$ & $(-10.60)$ & & & & & & \\
\hline \multirow[t]{2}{*}{ Gender } & $-0.0298^{\star * *}$ & & $-0.0249^{* * *}$ & & & & & \\
\hline & $(-5.25)$ & & $(-4.43)$ & & & & & \\
\hline \multirow[t]{2}{*}{ Edubg } & $0.0281^{\star * *}$ & & & $0.0449^{\star * *}$ & & & & \\
\hline & $(4.64)$ & & & $(7.56)$ & & & & \\
\hline \multirow[t]{2}{*}{ Spe } & $0.0006^{*}$ & & & & $0.0006^{* *}$ & & & \\
\hline & $(1.81)$ & & & & $(2.25)$ & & & \\
\hline \multirow[t]{2}{*}{ Partner } & $0.0196^{\star * *}$ & & & & & $0.0118^{* *}$ & & \\
\hline & $(2.92)$ & & & & & $(2.22)$ & & \\
\hline \multirow[t]{2}{*}{ Exp } & $0.0031^{* * *}$ & & & & & & -0.0008 & \\
\hline & $(3.88)$ & & & & & & $(-1.57)$ & \\
\hline \multirow[t]{2}{*}{ Busyness } & $0.0031^{* *}$ & & & & & & & $0.0040^{* * *}$ \\
\hline & $(2.37)$ & & & & & & & (3.63) \\
\hline \multirow[t]{2}{*}{ Big10 } & $0.1062^{* * *}$ & $0.1075^{* * *}$ & $0.1132^{* * *}$ & $0.1114^{\star * *}$ & $0.1131^{* * *}$ & $0.1137^{* * *}$ & $0.1121^{\star * *}$ & $0.1131^{* * *}$ \\
\hline & (19.72) & (19.93) & (21.04) & (20.69) & $(21.02)$ & (21.10) & (20.84) & $(21.01)$ \\
\hline \multirow[t]{2}{*}{ Em } & $2.3665^{\star * *}$ & $2.3792^{\star * *}$ & $2.3677^{\star * \star}$ & $2.3782^{\star * *}$ & $2.3742^{\star * *}$ & $2.3697^{\star * *}$ & $2.3795^{\star * *}$ & $2.3762^{\star * \star}$ \\
\hline & (16.76) & $(16.81)$ & (16.69) & (16.78) & $(16.73)$ & $(16.70)$ & $(16.80)$ & $(16.75)$ \\
\hline \multirow[t]{2}{*}{ Complexity } & $0.0887^{* * *}$ & $0.0887^{* * *}$ & $0.0926^{* * *}$ & $0.0905^{\star * *}$ & $0.0934^{* * *}$ & $0.0928^{* * *}$ & $0.0915^{\star * *}$ & $0.0922^{* * *}$ \\
\hline & $(4.73)$ & $(4.72)$ & $(4.92)$ & $(4.81)$ & $(4.96)$ & $(4.93)$ & $(4.87)$ & $(4.90)$ \\
\hline \multirow[t]{2}{*}{ Switch } & $-0.0722^{* * *}$ & $-0.0795^{\star * *}$ & $-0.0793^{* * *}$ & $-0.0791^{\star * *}$ & $-0.0777^{\star * *}$ & $-0.0797^{\star * *}$ & $-0.0799^{* * *}$ & $-0.0769^{\star * *}$ \\
\hline & $(-7.43)$ & $(-8.21)$ & $(-8.17)$ & $(-8.16)$ & $(-7.96)$ & $(-8.20)$ & $(-8.26)$ & $(-7.89)$ \\
\hline \multirow[t]{2}{*}{ Opinion } & $0.1753^{* * *}$ & $0.1741^{\star * *}$ & $0.1761^{\star * *}$ & $0.1726^{\star * *}$ & $0.1754^{\star * \star}$ & $0.1757^{\star * *}$ & $0.1742^{\star * *}$ & $0.1760^{* * *}$ \\
\hline & (10.30) & $(10.21)$ & $(10.30)$ & (10.11) & $(10.26)$ & (10.28) & $(10.21)$ & (10.30) \\
\hline \multirow[t]{2}{*}{ Lev } & $-0.0752^{\star * *}$ & $-0.0807^{\star * *}$ & $-0.0846^{* * *}$ & $-0.0823^{* * *}$ & $-0.0853^{* * *}$ & $-0.0848^{\star * *}$ & $-0.0849^{* * *}$ & $-0.0835^{\star * *}$ \\
\hline & $(-4.72)$ & $(-5.05)$ & $(-5.29)$ & $(-5.15)$ & $(-5.32)$ & $(-5.29)$ & $(-5.32)$ & $(-5.21)$ \\
\hline \multirow[t]{2}{*}{ Size } & $0.8386^{* * *}$ & $0.8412^{* * *}$ & $0.8420^{* * *}$ & $0.8396^{* * *}$ & $0.8422^{* * *}$ & $0.8418^{\star * *}$ & $0.8422^{\star * *}$ & $0.8432^{* * *}$ \\
\hline & $(136.08)$ & (136.69) & (136.55) & $(136.06)$ & $(136.54)$ & $(136.40)$ & (136.88) & (136.58) \\
\hline \multirow[t]{2}{*}{ Punish } & $0.0280^{* * *}$ & $0.0259^{* * *}$ & $0.0253^{* * *}$ & $0.0259^{\star * *}$ & $0.0247^{\star * *}$ & $0.0246^{* * *}$ & $0.0246^{* * *}$ & $0.0247^{* * *}$ \\
\hline & $(4.08)$ & $(3.76)$ & $(3.66)$ & $(3.75)$ & $(3.57)$ & $(3.56)$ & $(3.57)$ & $(3.57)$ \\
\hline \multirow[t]{2}{*}{ Loss } & $0.0507^{\star * *}$ & $0.0499^{* * *}$ & $0.0489^{* * *}$ & $0.0488^{* * *}$ & $0.0490^{* * *}$ & $0.0490^{\star * *}$ & $0.0498^{* * *}$ & $0.0492^{* * *}$ \\
\hline & $(5.25)$ & $(5.15)$ & (5.03) & $(5.03)$ & $(5.05)$ & $(5.05)$ & (5.14) & $(5.07)$ \\
\hline \multirow[t]{2}{*}{ Grow } & $-0.0006^{\star *}$ & $-0.0006^{\star *}$ & $-0.0007^{\star *}$ & $-0.0006^{\star \star}$ & $-0.0007^{\star *}$ & $-0.0006^{\star *}$ & $-0.0007^{\star *}$ & $-0.0006^{* *}$ \\
\hline & $(-2.11)$ & $(-2.21)$ & $(-2.26)$ & $(-2.20)$ & $(-2.24)$ & $(-2.22)$ & $(-2.24)$ & $(-2.21)$ \\
\hline Year/Ind & Control & Control & Control & Control & Control & Control & Control & Control \\
\hline \multirow[t]{2}{*}{ Constant } & $5.5120^{\star * *}$ & $5.4469^{* * *}$ & $5.2887^{* * *}$ & $5.2621^{* * *}$ & $5.2679^{* * *}$ & $5.2658^{* * *}$ & $5.2790^{* * *}$ & $5.2466^{* * *}$ \\
\hline & $(87.24)$ & (88.13) & $(88.47)$ & $(88.32)$ & $(88.32)$ & $(88.25)$ & (88.41) & (87.48) \\
\hline Obs. & 22,728 & 22,728 & 22,728 & 22,728 & 22,728 & 22,728 & 22,728 & 22,728 \\
\hline R-squared & 0.57 & 0.57 & 0.56 & 0.56 & 0.56 & 0.56 & 0.56 & 0.56 \\
\hline r2_a & 0.567 & 0.565 & 0.563 & 0.564 & 0.563 & 0.563 & 0.562 & 0.563 \\
\hline F & 785.4 & 923.1 & 916.5 & 919.2 & 915.4 & 915.4 & 917.8 & 916.0 \\
\hline
\end{tabular}

$\mathrm{t}$ statistics in parentheses ${ }^{*} \mathrm{p}<0.05,{ }^{* *} \mathrm{p}<0.01,{ }^{* * *} \mathrm{p}<0.001$. 
For control variables, there is a significant positive correlation between "Big 10 " accounting firms and the audit fee. The level of earnings management is significantly positively related to the audit fees. The complexity of economic business is significantly positively correlated with the audit fees. Whether to switch the firm is significantly negatively correlated with the audit fees. There is a significant positive correlation between the size of the auditee and the audit fees. Whether the company is punished is significantly positively related to the audit fees and the loss for the year has a significant positive correlation with the audit fees. The company's growth is positively correlated with the audit fees. Contrary to the expectation that the company's asset-liability ratio is significantly negatively correlated with the audit fee, indicating that the higher the asset-liability ratio, the lower the audit fees. The descriptive statistics shows that lev of the auditee is at a reasonable level. The higher of reasonable lev, the more power owned by creditors, which means managers must improve earnings quality, reduce the possibility of financial frauds, and reduce the likelihood of significant financial risks of the company, thereby reducing audit fees [63]. Besides, the increase of medium and long term liability conveys the signal of good corporate governance referring to Signaling Theory.

\section{4) Robustness Tests}

This paper carries out the robustness tests on the empirical results by 2 methods. In the first robustness test, we measure the explanatory variables in another way, by combining the two auditor features for the year into an integrated variable; and the other variables in the model do not change. The definitions of variable of robustness test 1 are presented in Table 4. The regression results are shown in Table 5 that the results are almost consistent and the explanatory variables still have significant effects on the explanatory variables in these two robustness tests.

In the second robustness test, we expand the year length, starting from 2007 to measure whether the relationship between auditor characteristics and audit fees is influenced by external policy. It is found from Table 5 that the results are almost consistent, illustrating that the impact of the individual characteristics of the auditors on the audit fees does not change by revision of audit standards.

Table 4. Variable definition of robustness test 1.

Code
is 1 if both auditors' ages are above medium of age for the year, and 0 otherwise
Gender
is 1 if both auditors are men, and 0 otherwise
is 1 if both auditors have bachelor degrees or above, and 0 otherwise
Partner
is 1 if both auditors' industry specializations are above medium of industry specialization for the year, and 0 otherwise
is 1 if both auditors are partners, and 0 otherwise
is 1 if both auditors' number of audit year is above medium of number of audit year for the year, and 0 otherwise
is 1 if both auditors' busyness is above medium of busyness for the year, and 0 otherwise


Table 5. Regression results of robustness tests.

\begin{tabular}{|c|c|c|}
\hline & (9) & (10) \\
\hline \multirow[t]{2}{*}{ Age } & $-0.0947^{\star * *}$ & $-0.0056^{* * *}$ \\
\hline & $(-10.38)$ & $(-12.09)$ \\
\hline \multirow[t]{2}{*}{ Gender } & -0.0128 & $-0.0272^{\star * *}$ \\
\hline & $(-1.64)$ & $(-5.34)$ \\
\hline \multirow[t]{2}{*}{ Edubg } & $0.0266^{* * *}$ & $0.0276^{* * *}$ \\
\hline & $(3.11)$ & $(5.07)$ \\
\hline \multirow[t]{2}{*}{ Spe } & 0.0072 & 0.0003 \\
\hline & $(0.84)$ & $(1.26)$ \\
\hline \multirow[t]{2}{*}{ Partner } & $0.0190^{* *}$ & $0.0258^{* * *}$ \\
\hline & $(2.08)$ & $(4.34)$ \\
\hline \multirow[t]{2}{*}{ Exp } & $0.0295^{* * *}$ & $0.0021^{\star * *}$ \\
\hline & $(3.22)$ & $(3.09)$ \\
\hline \multirow[t]{2}{*}{ Busyness } & $0.0138^{*}$ & $0.0036^{* * *}$ \\
\hline & $(1.73)$ & $(3.11)$ \\
\hline \multirow[t]{2}{*}{ Big10 } & $0.1049^{* * *}$ & $0.1308^{\star * *}$ \\
\hline & (13.38) & (25.59) \\
\hline \multirow[t]{2}{*}{$\mathrm{Em}$} & $2.3223^{* * *}$ & $2.1035^{\star * *}$ \\
\hline & (11.39) & $(20.66)$ \\
\hline \multirow[t]{2}{*}{ Complexity } & $0.0803^{\star * *}$ & $-0.1181^{* * *}$ \\
\hline & $(2.98)$ & $(-6.27)$ \\
\hline \multirow[t]{2}{*}{ Switch } & $-0.0679^{* * *}$ & $-0.0601^{* * *}$ \\
\hline & $(-4.79)$ & $(-7.03)$ \\
\hline \multirow[t]{2}{*}{ Opinion } & $0.1686^{* * *}$ & $0.1735^{\star * *}$ \\
\hline & $(6.91)$ & (13.24) \\
\hline \multirow[t]{2}{*}{ Lev } & $-0.0761^{\star * *}$ & $0.0190^{\star * *}$ \\
\hline & $(-3.32)$ & (18.47) \\
\hline \multirow[t]{2}{*}{ Size } & $0.8387^{* * *}$ & $0.7987^{\star * *}$ \\
\hline & $(94.47)$ & (170.19) \\
\hline \multirow[t]{2}{*}{ Punish } & $0.0272^{* * *}$ & $0.0216^{* * *}$ \\
\hline & $(2.75)$ & $(3.49)$ \\
\hline \multirow[t]{2}{*}{ Loss } & $0.0534^{* * *}$ & $0.0613^{* * *}$ \\
\hline & $(3.84)$ & $(7.49)$ \\
\hline \multirow[t]{2}{*}{ Grow } & $-0.0007^{\star}$ & -0.0000 \\
\hline & $(-1.75)$ & $(-0.54)$ \\
\hline \multirow[t]{2}{*}{ Constant } & $5.3157^{\star * *}$ & $5.7842^{\star * *}$ \\
\hline & $(61.58)$ & $(113.60)$ \\
\hline Observations & 11072 & 29094 \\
\hline R-squared & 0.57 & 0.57 \\
\hline $\mathrm{r} 2 \_\mathrm{a}$ & 0.566 & 0.572 \\
\hline F & 380.4 & 949.1 \\
\hline
\end{tabular}

$\mathrm{t}$ statistics in parentheses ${ }^{*} \mathrm{p}<0.05,{ }^{* *} \mathrm{p}<0.01,{ }^{* * *} \mathrm{p}<0.001$. 


\section{Conclusions}

This paper bases on the data of listed companies in China from 2010 to 2015 to conduct empirical study about the influence of auditor's individual characteristics on audit fees, selecting age, gender, education background, position, the number of audit year and busyness as explanatory variables. The empirical results show that in addition to the factors of audit client level and accounting firm level, the auditor's individual characteristics also have influence on audit fees. The age, gender, educational background, industry specialization, position, number of audit year and busyness of auditors all significantly related to audit fees. The auditors who are female, younger, partner and have higher degree of education, more audit experience, and higher reputation tend to gain favors of the audit clients and obtain higher audit fees.

This paper may provide the following suggestions. Firstly, audit industry should strengthen the professional abilities of the individual auditors. The empirical results show that when choosing audit services, the audit clients not only consider the characteristics of the firm, but also consider the individual characteristics of auditors, and they are willing to pay audit fee premiums for the auditors who deliver the "high quality" signals. Therefore, the audit firm should strengthen the professional education and on-the-job training of auditors, and pay attention to the cultivation of industry expertise, to improve audit quality and receive higher audit fees. To improve auditors' education degrees, the firm should introduce outstanding graduates with highly educated backgrounds. On the other hand, the audit firm should build a reasonable incentive mechanism to encourage auditors to receive continuing education to continuously improve their own professional abilities. In terms of practical experience, audit firms need to pay attention to the experience of auditors and guide them to accumulate industrial specialization.

Secondly, the audit firm should pay attention to the disclosure of the characteristics of the individual auditors, because the firms merely disclose some concise information, such as the firm's comprehensive ranking nowadays. However, according to the conclusion of this paper, audit clients care about individual auditors and are willing to pay different audit fees. Therefore, more disclosure of individual auditors' information will reduce the search costs of audit clients and help clients select appropriate audit services more efficiently.

\section{Research Limitations and Future Research Directions}

This paper proves that the individual characteristics of auditors will have an impact on audit fees. And this paper mainly measures the demographic characteristics and practicing characteristics of the auditors from several aspects. However, the individual characteristic is an abstract concept. In addition to the features used in this paper, there are many features that affect the auditor's decision-making. For example, Environment, personal character, economic status and other factors. However, due to the difficulty of data collection, individual characteristics cannot be fully defined. Therefore, in the future research, we can 
include more comprehensive characteristic of auditors to examine the audit fees at individual auditor level.

\section{References}

[1] Simunic, D.A. (1980) The Pricing of Audit Services: Theory and Evidence. Journal of Accounting Research, 18, 161-190. https://doi.org/10.2307/2490397

[2] Francis, J.R. (1984) The Effect of Audit Firm Size on Audit Prices: A Study of The Australian Market. Journal of Accounting and Economics, 6, 133-151.

[3] Francis, J.R. and Stokes, D.J. (1986) Audit Prices, Product Differentiation, and Scale Economies: Further Evidence from the Australian Market. Journal of Accounting Research, 24, 383-393. https://doi.org/10.2307/2491141

[4] Wu, L. (2003) The Determinants of Audit Fee: Evidence from Chinese Stock Market's First-Time Disclosure of Audit Fee. China Accounting Review, No. 1, 113-128.

[5] Lennox, C. (1999) Are Large Auditors More Accurate Than Small Auditors? Accounting and Business Research, 29, 217-227.

https://doi.org/10.1080/00014788.1999.9729582

[6] Krishnan, G.V. (2003) Audit Quality and the Pricing of Discretionary Accruals. Auditing. A Journal of Practice \& Theory, 22, 109-126.

https://doi.org/10.2308/aud.2003.22.1.109

[7] Taylor, M.H. (1997) The Market for Audit Services in Japan. Pacific Accounting Review, 9, 59-74.

[8] Simon, D.T. and Taylor, M.H. (2002) A Survey of Audit Pricing in Ireland. International Journal of Auditing, 6, 3-12. https://doi.org/10.1111/j.1099-1123.2002.tb00002.x

[9] Craswell, A.T., Francis, J.R. and Taylor, S.L. (1995) Auditor Brand Name Reputations and Industry Specializations. Journal of Accounting and Economics, 20, 297322.

[10] DeFond, M.L., Francis, J.R. and Wong, T.J. (2000) Auditor Industry Specialization and Market Segmentation: Evidence from Hong Kong. Auditing. A Journal of Practice \& Theory, 19, 49-66. https://doi.org/10.2308/aud.2000.19.1.49

[11] Basioudis, I.G. and Francis, J.R. (2007) Big 4 Audit Fee Premiums for National and Office-Level Industry Leadership in the United Kingdom. Auditing. A Journal of Practice \& Theory, 26, 143-166. https://doi.org/10.2308/aud.2007.26.2.143

[12] Carson, E. and Fargher, N. (2007) Note on Audit Fee Premiums to Client Size and Industry Specialization. Accounting \& Finance, 47, 423-446. https://doi.org/10.1111/j.1467-629X.2007.00213.x

[13] Goodwin, J. and Wu, D. (2014) Is the Effect of Industry Expertise on Audit Pricing an Office-Level or a Partner-Level Phenomenon? Review of Accounting Studies, 19, 1532-1578. https://doi.org/10.1007/s11142-014-9285-8

[14] Ponemon, L.A. and Gabhart, D.R. (1990) Auditor Independence Judgments: A Cognitive-Developmental Model and Experimental Evidence. Contemporary Accounting Research, 7, 227-251. https://doi.org/10.1111/j.1911-3846.1990.tb00812.x

[15] Trompeter, G. (1994) The Effect of Partner Compensation Schemes and Generally Accepted Accounting Principles on Audit Partner Judgment. Auditing, 13, 56.

[16] Emby, C., Gelardi, A.M. and Lowe, D.J. (2002) A Research Note on the Influence of Outcome Knowledge on Audit Partners' Judgments. Behavioral Research in Accounting, 14, 87-103. https://doi.org/10.2308/bria.2002.14.1.87

[17] Ayers, S. and Kaplan, S.E. (2003) Review Partners' Reactions to Contact Partner 
Risk Judgments of Prospective Clients. Auditing. A Journal of Practice \& Theory, 22, 29-45. https://doi.org/10.2308/aud.2003.22.1.29

[18] Chin, C. and Chi, H. (2008) Gender Differences in Audit Quality. 2008 American Accounting Association Annual Meeting. https://ssrn.com/abstract=1149405

[19] Sundgren, S. and Svanström, T. (2014) Auditor-in-Charge Characteristics and Going-Concern Reporting. Contemporary Accounting Research, 31, 531-550. https://doi.org/10.1111/1911-3846.12035

[20] Gul, F.A., Ma, M. and Lai, K. (2012) Auditing Multiple Public Clients, PartnerClient Tenure and Audit Quality. Social Science Electronic Publishing, Rochester.

[21] Burrows, G. and Black, C. (1998) Profit Sharing in Australian Big 6 Accounting Firms: An Exploratory Study. Accounting, Organizations and Society, 23, 517-530.

[22] Duff, A. (2009) Measuring Audit Quality in an Era of Change: An Empirical Investigation of UK Audit Market Stakeholders in 2002 and 2005. Managerial Auditing Journal, 24, 400-422. https://doi.org/10.1108/02686900910956784

[23] Firth, M. (1985) An Analysis of Audit Fees and Their Determinants in New-Zealand. Auditing. A Journal of Practice \& Theory, 4, 23-37.

[24] Han, H. and Zhou, S. (2003) A Research of Audit Fee at Chinese Security Markets-The Empirical Analysis of Listed Companies. Management World, 2003, 15 22.

[25] Liu, B., Ye, J. and Liao, Y. (2003) Determinants of Audit Fee of Chinese Listed Companies-Empirical Data of Shenzhen and Shanghai in 2001. Auditing Research, No. 1, 44-47.

[26] Zhang, J. and Xu, Y. (2005) The Determinants of Audit Fees: Evidence from the China's Listed Companies in 2001-2003. China Accounting Review, 3, 99-116.

[27] Fang, Q. and Li, X. (2011) A Study on the Influence by Merges of Accounting Firms on Audit Fees. The Chinese Certified Public Accountant, No. 2, 63-69.

[28] Collier, P. and Gregory, A. (1996) Audit Committee Effectiveness and the Audit Fee. European Accounting Review, 5, 177-198. https://doi.org/10.1080/09638189600000012

[29] Carcello, J.V., Hermanson, D.R., Neal, T.L. and Riley, R.A. (2002) Board Characteristics and Audit Fees. Contemporary Accounting Research, 19, 365-384. https://doi.org/10.1506/CHWK-GMQ0-MLKE-K03V

[30] Cai, J. (2007) Corporate Governance. Audit Risk and Audit Fees. Auditing Research, No. 3, 65-71.

[31] He, Q. and Liu, W. (2015) Managerial Ability and Audit Fee. Accounting Research, No. 1, 82-89.

[32] Bell, T.B., Landsman, W.R. and Shackelford, D.A. (2001) Auditors' Perceived Business Risk and Audit Fees: Analysis and Evidence. Journal of Accounting Research, 39, 35-43. https://doi.org/10.1111/1475-679X.00002

[33] Abbott, L.J., Parker, S. and Peters, G.F. (2006) Earnings Management, Litigation Risk, and Asymmetric Audit Fee Responses. Auditing. A Journal of Practice \& Theory, 25, 85-98. https://doi.org/10.2308/aud.2006.25.1.85

[34] Zhao, G. and Wang, S. (2008) Earning Management, Affiliated Transaction and Auditor Characteristics. Journal of Zhongnan University of Economics and Law, $168,58-62$.

[35] Song, Y. (2011) Audit Risk, Audit Pricing and Related Bargaining Power-Evidence from Listed Companies That Are Investigated or Punished by Supervisors. Accounting Research, No. 2, 79-84, 97. 
[36] Li, B. and Wang, P. (2006) Board Characteristics and Ratios of Audit Fee to Asset. China Accounting Review, 4, 105-118.

[37] Knechel, W.R., Niemi, L. and Sundgren, S. (2008) Determinants of Auditor Choice: Evidence from a Small Client Market. International Journal of Auditing, 12, 65-88. https://doi.org/10.1111/j.1099-1123.2008.00370.x

[38] Gardner, M. and Steinberg, L. (2005) Peer Influence on Risk Taking, Risk Preference, and Risky Decision Making in Adolescence and Adulthood: An Experimental Study. Developmental Psychology, 41, 625. https://doi.org/10.1037/0012-1649.41.4.625

[39] Paulsen, D.J., Platt, M.L., Huettel, S.A. and Brannon, E.M. (2012) From Risk-Seeking to Risk-Averse: The Development of Economic Risk Preference from Childhood to Adulthood. Frontiers in Psychology, 3, 313. https://doi.org/10.3389/fpsyg.2012.00313

[40] Chung, J. and Monroe, G.S. (2001) A Research Note on the Effects of Gender and Task Complexity on an Audit Judgment. Behavioral Research in Accounting, 13, 111-125. https://doi.org/10.2308/bria.2001.13.1.111

[41] Borkowski, S.C. and Ugras, Y.J. (1992) The Ethical Attitudes of Students as a Function of Age, Sex and Experience. Journal of Business Ethics, 11, 961-979. https://doi.org/10.1007/BF00871962

[42] Wilson, M. and Daly, M. (1985) Competitiveness, Risk Taking, and Violence: The Young Male Syndrome. Ethology and Sociobiology, 6, 59-73.

[43] Graham, J.F., Stendardi Jr., E.J., Myers, J.K. and Graham, M.J. (2002) Gender Differences in Investment Strategies: An Information Processing Perspective. International Journal of Bank Marketing, 20, 17-26. https://doi.org/10.1108/02652320210415953

[44] Eckel, C.C. and Grossman, P.J. (2002) Sex Differences and Statistical Stereotyping in Attitudes toward Financial Risk. Evolution and Human Behavior, 23, 281-295.

[45] Fellner, G. and Maciejovsky, B. (2007) Risk Attitude and Market Behavior: Evidence from Experimental Asset Markets. Journal of Economic Psychology, 28, 338-350.

[46] Shi, D. and Cheng, J. (2011) The Effect of Auditor's Gender Composition on the Audit Quality and Audit Fees: Empirical Evidence from China. Journal of Audit \& Economics, 26, 38-46.

[47] Spence, A.M. (1974) Market Signaling, Information Transfer in Hiring and Related Processes. Market Signaling: Informational Transfer in Hiring and Related Screening Processes. Harvard University Press, Cambridge.

[48] Lichtenstein, S. and Fischhoff, B. (1977) Do Those Who Know More Also Know More about How Much They Know? Organizational Behavior and Human Performance, 20, 159-183.

[49] Bonner, S.E. and Walker, P.L. (1994) The Effects of Instruction and Experience on the Acquisition of Auditing Knowledge. Accounting Review, 69, 157-178.

[50] Ye, Q. and Yu, Z. (2011) Auditors' Individual Characteristics and Audit Quality. Journal of Shanxi Finance and Economics University, 2, 117-124.

[51] Karjalainen, J. (2011) Audit Partner Industry Specialization and Earnings Quality of Privately-Held Companies. https://ssrn.com/abstract=1766437 https://doi.org/10.2139/ssrn.1766437

[52] Zerni, M. (2012) Audit Partner Specialization and Audit Fees: Some Evidence from Sweden. Contemporary Accounting Research, 29, 312-340. https://doi.org/10.1111/j.1911-3846.2011.01098.x

[53] Miller, T. (1992) Do We Need to Consider the Individual Auditor When Discussing 
Auditor Independence? Accounting, Auditing \& Accountability Journal, 5, 74-84. https://doi.org/10.1108/09513579210011871

[54] De Angelo, L.E. (1981) Auditor Size and Audit Quality. Journal of Accounting \& Economics, 3, 183-199.

[55] Chi, W., Myers, L.A., Omer, T.C. and Xie, H. (2013) The Effects of Audit Partner Pre-Client and Client-Specific Experience on Audit Quality and on Perceptions of Audit Quality. Review of Accounting Studies, 22, 361-391. https://doi.org/10.1007/s11142-016-9376-9

[56] Libby, R. and Frederic, D.M. (1990) Experience and the Ability to Explain Audit Findings. Journal of Accounting Research, 28, 348-367. https://doi.org/10.2307/2491154

[57] Tubbs, R.M. (1992) The Effect of Experience on the Auditor's Organization and Amount of Knowledge. Accounting Review, 67, 783-801.

[58] Hammersley, J.S. (2006) Pattern Identification and Industry-Specialist Auditors. The Accounting Review, 81, 309-336. https://doi.org/10.2308/accr.2006.81.2.309

[59] Kaplan, S.E., O’Donnell, E.F. and Arel, B.M. (2008) The Influence of Auditor Experience on the Persuasiveness of Information Provided by Management. Auditing. A Journal of Practice \& Theory, 27, 67-83. https://doi.org/10.2308/aud.2008.27.1.67

[60] Fich, E.M. and Shivdasani, A. (2006) Are Busy Boards Effective Monitors? The Journal of Finance, 61, 689-724. https://doi.org/10.1111/j.1540-6261.2006.00852.x

[61] Balsam, S., Krishnan, J. and Yang, J.S. (2003) Auditor Industry Specialization and Earnings Quality. Auditing: A Journal of Practice \& Theory, 22, 71-97. https://doi.org/10.2308/aud.2003.22.2.71

[62] Goodwin, J. and Wu, D. (2016) What Is The Relationship between Audit Partner Busyness and Audit Quality? Contemporary Accounting Research, 33, 341-377. https://doi.org/10.1111/1911-3846.12129

[63] Jensen, M. and Meckling, W. (1976) Theory of the Firm: Management Behavior, Agency. Cost and Ownership Structures. Journal of Financial Economics, 3, 77.

Submit or recommend next manuscript to SCIRP and we will provide best service for you:

Accepting pre-submission inquiries through Email, Facebook, LinkedIn, Twitter, etc. A wide selection of journals (inclusive of 9 subjects, more than 200 journals)

Providing 24-hour high-quality service

User-friendly online submission system

Fair and swift peer-review system

Efficient typesetting and proofreading procedure

Display of the result of downloads and visits, as well as the number of cited articles

Maximum dissemination of your research work

Submit your manuscript at: http://papersubmission.scirp.org/

Or contact ojacct@scirp.org 